\title{
Front Matter: Volume 7459
}

, "Front Matter: Volume 7459," Proc. SPIE 7459, Ocean Remote Sensing: Methods and Applications, 745901 (1 September 2009); doi:

10.1117/12.844699

SPIE Event: SPIE Optical Engineering + Applications, 2009, San Diego, California, SPIE. United States 


\section{PROCEEDINGS OF SPIE}

\section{Ocean Remote Sensing: Methods and Applications}

Robert J. Frouin

Editor

2 August 2009

San Diego, California, United States

Sponsored and Published by

SPIE

Volume 7459

Proceedings of SPIE, 0277-786X, v. 7459 
The papers included in this volume were part of the technical conference cited on the cover and title page. Papers were selected and subject to review by the editors and conference program committee. Some conference presentations may not be available for publication. The papers published in these proceedings reflect the work and thoughts of the authors and are published herein as submitted. The publisher is not responsible for the validity of the information or for any outcomes resulting from reliance thereon.

Please use the following format to cite material from this book:

Author(s), "Title of Paper," in Ocean Remote Sensing: Methods and Applications, edited by Robert J. Frouin, Proceedings of SPIE Vol. 7459 (SPIE, Bellingham, WA, 2009) Article CID Number.

ISSN 0277-786X

ISBN 9780819477491

Published by

SPIE

P.O. Box 10, Bellingham, Washington 98227-0010 USA

Telephone +1 3606763290 (Pacific Time) · Fax +1 3606471445

SPIE.org

Copyright (c) 2009, Society of Photo-Optical Instrumentation Engineers

Copying of material in this book for internal or personal use, or for the internal or personal use of specific clients, beyond the fair use provisions granted by the U.S. Copyright Law is authorized by SPIE subject to payment of copying fees. The Transactional Reporting Service base fee for this volume is $\$ 18.00$ per article (or portion thereof), which should be paid directly to the Copyright Clearance Center (CCC), 222 Rosewood Drive, Danvers, MA 01923. Payment may also be made electronically through CCC Online at copyright.com. Other copying for republication, resale, advertising or promotion, or any form of systematic or multiple reproduction of any material in this book is prohibited except with permission in writing from the publisher. The CCC fee code is 0277-786X/09/\$18.00.

Printed in the United States of America.

Publication of record for individual papers is online in the SPIE Digital Library.

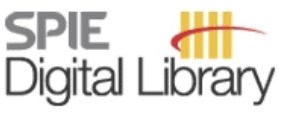

SPIEDigitalLibrary.org

Paper Numbering: Proceedings of SPIE follow an e-First publication model, with papers published first online and then in print and on CD-ROM. Papers are published as they are submitted and meet publication criteria. A unique, consistent, permanent citation identifier (CID) number is assigned to each article at the time of the first publication. Utilization of CIDs allows articles to be fully citable as soon they are published online, and connects the same identifier to all online, print, and electronic versions of the publication. SPIE uses a six-digit CID article numbering system in which:

- The first four digits correspond to the SPIE volume number.

- The last two digits indicate publication order within the volume using a Base 36 numbering system employing both numerals and letters. These two-number sets start with 00, 01, 02, 03, 04 , $05,06,07,08,09,0 A, 0 B \ldots$. OZ, followed by 10-1Z, 20-2Z, etc.

The CID number appears on each page of the manuscript. The complete citation is used on the first page, and an abbreviated version on subsequent pages. Numbers in the index correspond to the last two digits of the six-digit CID number. 


\section{Contents}

vii Conference Committee

\section{SESSION 1 ATMOSPHERIC CORRECTION OF OCEAN COLOR IMAGERY}

745903 Influence of thin cirrus clouds on ocean color products [7459-03]

G. Meister, Futuretech Corp. (United States); B. A. Franz, C. R. McClain, NASA Goddard Space Flight Ctr. (United States)

745904 Assessment of $\mathbf{4 1 2 n m}$ bio-optical reflectance estimator for use in atmospheric correction [7459-04]

B. Gross, M. Vargas, J. Zhou, A. Gilerson, F. Moshary, S. Ahmed, The City College of New York (United States)

745905 Noise and model uncertainties in ocean color remote sensing [7459-05]

R. Frouin, Univ. of California, San Diego (United States); B. Pelletier, CNRS, Univ. Montpellier II (France)

745906 Environmental effects in ocean color remote sensing [7459-06]

R. Frouin, Scripps Institution of Oceanography (United States); P.-Y, Deschamps, Scripps Institution of Oceanography (United States) and HYGEOS (France); F. Steinmetz, HYGEOS (France)

SESSION 2 MODELING AND INVERSION OF MARINE OPTICAL PROPERTIES

745909 Inversion of inherent optical properties of water using artificial neural network techniques for coastal water [7459-08]

I. Ioannou, J. Zhou, A. Gilerson, B. Gross, F. Moshary, S. Ahmed, The City College of New York (United States)

7459 OA IOP from reflectance measurements to obtain the Kd coefficient: application to the Gabon and Congo coastal waters [7459-09]

M. Schmeltz, J.-M. Froidefond, OASU-EPOC, CNRS, Univ. Bordeaux 1 (France); F. Jourdain, SHOM (France); N. Martiny, OASU-EPOC, CNRS, Univ. Bordeaux 1 (France)

7459 OB Evaluation of solar stimulated CDOM fluorescence and its impact on the closure of remote sensing reflectance [7459-10]

J. Zhou, A. Tonizzo, I. loannou, S. Hlaing, A. Gilerson, B. Gross, F. Moshary, S. Ahmed, The City College of New York (United States) 
7459 OD A cross-calibrated multiple plafform ocean surface wind data set [7459-12] R. Atlas, NOAA (United States); R. N. Hoffman, Atmospheric and Environmental Research, Inc. (United States); J. Ardizzone, NASA Goddard Space Flight Ctr. (United States)

7459 OE Satellite observation and model simulation of water furbidity in the Chesapeake Bay [7459-13]

X. Liu, NOAA/NESDIS/Ctr. for Satellite Applications and Research (United States) and SP Systems Inc. (United States); M. Wang, NOAA/NESDIS/Ctr. for Satellite Applications and Research (United States); W. Shi, NOAA/NESDIS/Ctr. for Satellite Applications and Research (United States) and CIRA at Colorado State Univ. (United States)

7459 OF Spectral variability of airborne ocean color data linked to variations in lidar backscattering profiles [7459-25]

M. A. Montes-Hugo, Mississippi State Univ. (United States) and U.S. Naval Research Lab. (United States); R. Gould, U.S. Naval Research Lab. (United States); Z. Lee, Mississippi State Univ. (United States); R. Arnone, D. Gray, U.S. Naval Research Lab. (United States);

J. Churnside, NOAA (United States)

7459 OG Ocean color response to an episode of heavy rainfall in the lagoon of New Caledonia [7459-15]

C. Dupouy, Ctr. IRD de Nouméa (New Caledonia) and Univ. de la Méditerranée (France); R. Frouin, Scripps Institution of Oceanography (United States); R. Röttgers, GKSS (Germany); J. Neveux, Univ. Pierre et Marie Curie, Paris VI (France); F. Gallois, J.-Y. Panché, Ctr. IRD de Nouméa (United States); P. Gerard, Ctr. IRD de Nouméa (France); C. Fontana, Univ. de la Méditerranée (United States); C. Pinazo, Univ. de la Méditerranée (France); S. Ouillon, Institut de Recherche pour le Développement (New Caledonia); A. Minghelli-Roman, LSEET, CNRS (France)

\section{SESSION 4 NEW SENSORS AND MEASUREMENT CONCEPTS}

$7459 \mathrm{OH} \quad$ Development of the GOCl data processing system and establishment of Korea Ocean Satellite Center [7459-16]

Y.-H. Ahn, S. Cho, H.-J. Han, C.-S. Yang, Korea Ocean Research and Development Institute (Korea, Republic of)

7459 Ol Prelaunch characterization of the Geostationary Ocean Color Imager [7459-17]

S. Cho, Y.-H. Ahn, H.-J. Han, J.-H. Ryu, Korea Ocean Research and Development Institute (Korea, Republic of)

7459 ON Beyond the first optical depth: fusing optical data from ocean color imagery and gliders [7459-24]

M. A. Montes-Hugo, Mississippi State Univ. (United States) and U.S. Naval Research Lab. (United States); R. Gould, R. Arnone, U.S. Naval Research Lab. (United States); H. Ducklow, The Ecosystems Ctr. (United States); K. Carder, D. English, Univ. of South Florida (United States); O. Schofield, J. Kerfoot, Rutgers Univ. (United States) 
POSTER SESSION

745900 Deep-water chlorophyll concentration global time series fluctuation [7459-22]

T. Holden, D. Sunil, E. Cheung, D. Cotten, D. Klarberg, G. Tremberger, Jr., T. Nasar, J. Taylor, P. Marchese, T. Cheung, CUNY Queensborough Community College (United States)

Author Index 
Downloaded From: https://www.spiedigitallibrary.org/conference-proceedings-of-spie on 26 Apr 2023

Terms of Use: https://www.spiedigitallibrary.org/terms-of-use 


\title{
Conference Committee
}

\author{
Conference Chair \\ Robert J. Frouin, Scripps Institution of Oceanography (United States) \\ Program Track Chair \\ Allen H.-L. Huang, University of Wisconsin, Madison (United States) \\ Session Chairs \\ 1 Atmospheric Correction of Ocean Color Imagery \\ Robert J. Frouin, Scripps Institution of Oceanography (United States) \\ 2 Modeling and Inversion of Marine Optical Properties \\ Hubert Loisel, Université du Littoral Côte d'Opale (France) \\ 3 Applications from Existing Satellite Missions \\ Robert J. Frouin, University of California, San Diego (United States) \\ $4 \quad$ New Sensors and Measurement Concepts \\ Seongick Cho, Korea Ocean Research and Development Institute \\ (Korea, Republic of)
}


Downloaded From: https://www.spiedigitallibrary.org/conference-proceedings-of-spie on 26 Apr 2023

Terms of Use: https://www.spiedigitallibrary.org/terms-of-use 